\title{
Experimental researches on poultry manure combustion in co-combustion with biomass
}

\author{
Gheorghe Lăzăroiu ${ }^{1 *}$, Gabriel Paul Negreanu ${ }^{2}$, Ionel Pîșă ${ }^{2}$, Rodica Manuela Grigoriu ${ }^{1}$, and Dana-Alexandra \\ Ciupăgeanu ${ }^{1}$ \\ ${ }^{1}$ Power Engineering Faculty, University Politehnica of Bucharest, Splaiul Independentei 313, 060042 Bucharest (Romania) \\ ${ }^{2}$ Mechanics and Mechatronics Faculty, University Politehnica of Bucharest, Splaiul Independentei 313, 060042 Bucharest \\ (Romania)
}

\begin{abstract}
Combustion of pure avian waste is strongly affected by its humidity content. According to the results of composition analysis, the initial humidity reaches up to $50 \%$, inhibiting direct combustion initiation and development. Drying of poultry waste is an alternative, but simple relatively long-term storage or thermal pre-processing, complicates the technological process of energy recovery and increases the associated costs. Co-combustion represents a promising solution to enrich the heating value of raw poultry manure. Experiments using biomass (in a mass fraction of up to $30 \%$ ) led to positive results in terms of efficiency. It is highlighted that the process depends on the quality of the woody biomass used for the mixture, but also on its bulk density, which causes an accelerated diffusion of air and influences the burning speed. This paper presents the experimental investigations on the co-combustion of poultry manure and woody biomass, performed on a $55 \mathrm{~kW}$ pilot boiler equipped with a post-combustion grate. The focus of the analysis is on the influence of the biomass bulk density and its heating value on the cocombustion process. The results obtained favor the development of a technology that is easy to apply and has a reduced cost. The technology investigated here is suitable for onsite applications in poultry farms, enabling meeting the energy demand based on co-combustion of resulting poultry waste.
\end{abstract}

\section{Introduction}

For the past decades, research interest in the energy field focuses on harmful emissions abatement and renewable energy technologies development and integration [1], [2]. It is remarked as, according to statistics released by the International Renewable Energy Agency, renewable energy sources (RES) almost doubled their cumulated generating capacity over the last decade [3].

One important but still less exploited RES is represented by the renewable waste [4]. For instance, waste mixtures resulting from bird houses operating cycles are characterized by increased soil restoration potential, so an alternative for their management is by spreading them as fertilizers [5], [6]. However, limitations regarding nitrogen content in agricultural areas imposed by 91/676/CEE Directive emphasize the need to intensively consider other management approaches such as treatments with energy recovery potential [7]. Combustion of poultry manure on site of poultry farms can be a solution for heating the halls, even to a certain extent, together with another fuel [8], [9].

The research developed in this paper aims to evaluate the efficiency of poultry manure co-combustion in combination with different types of solid biomass, such as forestry or agricultural. The approach presented meets also the objective of reducing the consumption of hydrocarbons (liquid or gaseous), according to the Paris Agreement. Specifically, the research refers only to the combustion of wet poultry manure, thus reducing the drying phase, usually naturally (which may be a polluting source by prolonged exposure to soil). The energy valorization of dry poultry manure has been previous research and achievements [4], [5], [10]. A mass participation of a maximum of $30 \%$ for poultry waste, which is fed above the burning biomass layer (only the fixed layer combustion technology for solid biomass) is envisaged.

The rest of the paper is structured as follows. Section 2 details the energy characteristics of poultry manure and the biomass which serves as thermal support.

\footnotetext{
${ }^{*}$ Corresponding author: glazaroiu@yahoo.com
} 


\section{Energy characteristics of poultry manure}

Solid biomass is a category of fuels characterized by a high volatile content, which involves a high ignition capacity, a low ash content, a very high oxygen content and a strong dependence of calorific value on moisture content [11], [12]. Usually, the humidity is required to be below $30 \%$, in which case the calorific value becomes higher than $12000 \mathrm{~kJ} / \mathrm{kg}$, superior to lignite [13].

In the present research, the solid biomass considered is represented by wood waste, while the agricultural biomass included vine ropes and tree branches.

The energy characteristics are assessed based on the elementary analysis, which includes the mass participations for carbon $(\mathrm{C})$, hydrogen $(\mathrm{H})$, sulfur $(\mathrm{S})$, oxygen $(\mathrm{O})$, nitrogen $(\mathrm{N})$, water $(\mathrm{W})$ and ash $(\mathrm{A})$, according to eq. (1). The index $i$ refers to the initial state, and the humidity is the total $\left(\mathrm{W}_{\mathrm{t}}^{\mathrm{i}}\right)$.

$$
\mathrm{C}_{\mathrm{i}}+\mathrm{Hi}+\mathrm{S}_{\mathrm{c}}^{\mathrm{i}}+\mathrm{Oi}+\mathrm{N}_{\mathrm{i}}+\mathrm{W}_{\mathrm{t}}^{\mathrm{i}}+\mathrm{A}_{\mathrm{i}}=100
$$

The calorific value can be calculated based on the elementary analysis. Flue gas emissions and air demand are determined by the stoichiometric relationships of combustion reactions. If only the lower calorific value $H_{i}^{i}$ is in $\mathrm{MJ} / \mathrm{kg}$, the carbon content $\mathrm{C}$, employing eqs. (2-4):

$$
\begin{array}{ll}
\mathrm{C}=0.0548929+0.023736 \mathrm{H}_{\mathrm{i}}^{\mathrm{i}} & {[\mathrm{kg} / \mathrm{kg}]} \\
\mathrm{V}_{\mathrm{g}}^{\mathrm{o}}=1.57933+0.217974 \mathrm{H}_{\mathrm{i}}^{\mathrm{i}} & {\left[\mathrm{m}_{\mathrm{N}}^{3} / \mathrm{kg}\right]} \\
V_{\mathrm{CO}_{2}}=0.101619+0.043991 \mathrm{H}_{\mathrm{i}}^{\mathrm{i}} & {\left[\mathrm{m}_{\mathrm{N}}^{3} / \mathrm{kg}\right]}
\end{array}
$$

Table 1 presents the energy characteristics of the biomass considered for the experimental tests.

Table 1. Energy characteristics of some solid biomass varieties.

\begin{tabular}{|c|c|c|c|c|c|c|c|}
\hline Biomass & $\mathbf{C i}$ & $\mathbf{H}_{\mathbf{i}}$ & $\mathbf{O}_{\mathbf{i}}$ & $\mathbf{N}_{\mathbf{i}}$ & $\mathbf{W}_{\mathbf{t}}^{\mathbf{i}}$ & $\mathbf{A}_{\mathbf{i}}$ & $\mathbf{H}_{\mathbf{i}}^{\mathbf{i}}$ \\
\cline { 2 - 8 } & $\%$ & $\%$ & $\%$ & $\%$ & $\%$ & $\%$ & $\mathrm{MJ} / \mathrm{kg}$ \\
\hline Dry wood & 46.7 & 5.1 & 33.6 & 0.6 & 10.5 & 3.5 & 17.15 \\
\hline $\begin{array}{c}\text { Wood with medium } \\
\text { humidity }\end{array}$ & 32.9 & 4.6 & 28.6 & 0.7 & 30 & 3.2 & 12.01 \\
\hline Sunflower stems & $37 \div 42$ & $4.1 \div 5.2$ & $35 \div 40$ & $1.2 \div 1.7$ & $11.1 \div 17.1$ & $3.3 \div 5.5$ & $13.6 \div 15.2$ \\
\hline Branches & 36.7 & 5.2 & 30.8 & 0.6 & 25.2 & 1.5 & 13.80 \\
\hline Vine ropes & $40 \div 43$ & $3.7 \div 4.9$ & $35 \div 42$ & $0.6 \div 2.5$ & $10 \div 26$ & $2.5 \div 4.5$ & $14.7 \div 15.8$ \\
\hline Corn cobs & $36 \div 39$ & $3.6 \div 5.1$ & $35 \div 44$ & $1.4 \div 3.8$ & $11.5 \div 17.1$ & $3.7 \div 5.7$ & $13.2 \div 15.0$ \\
\hline
\end{tabular}

In the experimental investigations, the poultry manure is pure or mixed with solid biomass, according to the operating conditions in the breeding halls.

The elementary analysis for biomass bed manure resulted within the ranges:

$$
\begin{aligned}
& \mathrm{C}_{\mathrm{i}}=12.4 \div 22.6 \% \\
& \mathrm{H}_{\mathrm{i}}=4.4 \div 5.4 \% \\
& \mathrm{~S}_{\mathrm{c}}^{\mathrm{i}}=1.8 \div 2.1 \% \\
& \mathrm{O}_{\mathrm{i}}=34.8 \div 37.6 \% \\
& \mathrm{~N}_{\mathrm{i}}=1.4 \div 2.4 \% \\
& \mathrm{~A}_{\mathrm{i}}=6.2 \div 12.8 \% \\
& \mathrm{~W}_{\mathrm{t}}^{\mathrm{i}}=33.8 \div 38.8
\end{aligned}
$$

Subsequently, the lower calorific value is equal to $\mathrm{H}_{\mathrm{i}}^{\mathrm{i}}=3840 \div 5950 \mathrm{~kJ} / \mathrm{kg}$ 
The elementary analysis of pure manure resulted within the ranges:

$$
\begin{aligned}
& \mathrm{C}_{\mathrm{i}}=12.4 \div 22.6 \% \\
& \mathrm{H}_{\mathrm{i}}=4.4 \div 5.4 \% \\
& \mathrm{~S}_{\mathrm{c}}^{\mathrm{i}}=1.8 \div 2.1 \% \\
& \mathrm{O}_{\mathrm{i}}=34.8 \div 37.6 \% \\
& \mathrm{~N}_{\mathrm{i}}=1.4 \div 2.4 \% \\
& \mathrm{~A}_{\mathrm{i}}=6.2 \div 12.8 \% \\
& \mathrm{~W}_{\mathrm{t}}^{\mathrm{i}}=33.8 \div 38.8
\end{aligned}
$$

The lower calorific value is evaluated in this case at $\mathrm{H}_{\mathrm{i}}^{\mathrm{i}}=3750 \div 5870 \mathrm{~kJ} / \mathrm{kg}$. It is noticeable that these values are slightly lower (less than $2 \%$ ) than the ones calculated in the previous case.

It is remarked that, according to the lower calorific value for poultry manure, it is required their combustion with a thermal support. In the present research, the thermal support comes from biomass, which has a calorific value about three times higher.

\section{Solid fuels combustion in fixed layer}

Fixed layer combustion is characterized by a concentration of it in a very small volume compared to the general size of the hearth. The result is a difficult penetration of air into the fuel layer, which leads to an excessive increase in pyrolysis - gasification processes, the resulting combustible gases continuing to burn in the rest of the hearth area [14]. Consequently, the overall combustion process depends outside the energy characteristics of the fuel and the porosity of the layer (the volume of voids in the fuel layer) [11].

However, the porosity responds positively to particles of a shape that can be approximated with a sphere and a strict particle size distribution. The higher the granulation, the lower the porosity of the fuel layer, as follows (the porosity was denoted by $\mathrm{m}$ ).

- $\quad$ Particle size $2 \div 25 \mathrm{~mm}, \mathrm{~m}=0.46 \div 0.48$

- $\quad$ Particle size $25 \div 50 \mathrm{~mm}, \mathrm{~m}=0.42 \div 0.45$

For biomass with shapes and sizes which are very far from spherical in shape (such as branches, vines, wood in the form of perches), it is proposed to replace the air intake criterion represented by porosity with the criterion "fuel layer density", $\rho_{c}$ in $\mathrm{kg} / \mathrm{m}^{3}$.

An oxygen-deficient fuel layer leads to a two-stages combustion mechanism, the first stage comprising the phase of gasification pyrolysis, with strong $\mathrm{CO}$ emission, the second stage leading to the final oxidation, with the formation of $\mathrm{CO}_{2}$ [15]. Figure 1 shows the physical model for two-stage combustion, the avian waste being attached to the second stage of combustion.

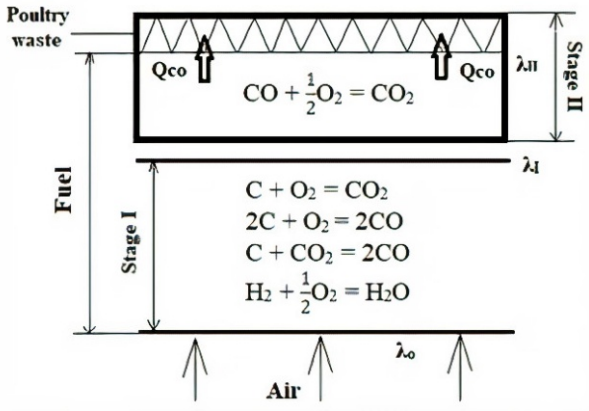

Fig. 1. Combustion scheme in a fixed layer of fuel with low porosity (high density), with two combustion steps

In stage I, the reactions take place:

$$
\begin{aligned}
& \mathrm{C}+\mathrm{O}_{2}=\mathrm{CO}_{2} \\
& 2 \mathrm{C}+\mathrm{O}_{2}=2 \mathrm{CO} \\
& \mathrm{C}+\mathrm{CO}_{2}=2 \mathrm{CO} \\
& \mathrm{H} 2+\frac{1}{2} \mathrm{O}_{2}=\mathrm{H}_{2} \mathrm{O}
\end{aligned}
$$


The reactions with formation of $\mathrm{CO}$ are a consequence of the air deficit. It can be considered that at the end of the first combustion stage the excess air is $\lambda I \approx 0.5 \lambda_{0}$ ( $\lambda_{\mathrm{o}}$ being the total excess air for the combustion in the layer). As for the combustion in the layer, the excess air $\lambda_{0} \approx 2$, we can consider $\lambda \mathrm{I}=1$ (stoichiometric combustion). An estimative calculation for biomass having the lower calorific value equal to $H_{i}^{i}=14 \mathrm{MJ} / \mathrm{kg}$, indicated the following combustion results:

- The volume of $\mathrm{CO}_{2}$ will be:

$$
\mathrm{V}_{\mathrm{CO}_{2}}=0.5 \cdot(0.101619+0.043991 \cdot 14)=0.358 \quad\left[\mathrm{~m}_{N}^{3} / \mathrm{kg}\right]
$$

- Volume of stoichiometric flue gas $(\lambda=1)$ emitted by burning the entire quantity of fuel:

$V_{g}^{o}=1.57133+0.217974 \cdot 14=4.63 \quad\left[m_{N}^{3} / \mathrm{kg}\right]$

- The concentration of $\mathrm{CO}_{2}$ in the stoichiometric volume of carbon gas is:

$\mathrm{CO}_{2}=\frac{\mathrm{v}_{\mathrm{CO}_{2}}}{V_{g}^{o}}=0.077 \frac{m_{N}^{3}}{m_{N}^{3}}=7.7 \%$

- The excess air $\lambda_{0}$ allowed will be self-distributed to the second combustion stage. The concentration of $\mathrm{CO}$ in the second stage depends on the degree of oxidation of carbon to $\mathrm{CO}_{2}$, and analytically for $1 \mathrm{~kg}$ of carbon is represented by the relation:

$\mathrm{CO}=34.7-1.65 \mathrm{CO}_{2} \quad[\%]$

- The heat released by burning CO in the second combustion stage will be:

$\mathrm{Qco}=\frac{C O}{100} \cdot H_{i, C O}^{i}\left[\frac{k J}{m_{N}^{3}}\right]$

where $H_{i, C O}^{i}$ is the lower calorific value of $\mathrm{CO}$, resulting in:

$\mathrm{Qco}=\frac{34.7-1.65 \mathrm{CO}_{2}}{100} \cdot H_{i, \mathrm{CO}}^{i} \quad\left[\frac{\mathrm{kJ}}{\mathrm{m}_{N}^{3}}\right]$

- $\quad$ For a fuel with a $\mathrm{C}_{\mathrm{i}} / 100$ carbon content, the equation becomes:

$Q_{C O}^{r}=\frac{C^{i}}{100} \cdot \frac{34.7-1.65 \mathrm{CO}_{2}}{100} \cdot H_{i, C O}^{i} \quad\left[\frac{k J}{m_{N}^{3}}\right]$,

$Q_{C O}^{r}$ represents the actual amount of CO released when a solid fuel is burned.

The low heat input released by the second-stage combustion of $\mathrm{CO}$, to support the combustion of poultry waste, leads to heavy ignition and entry into a gasification regime, with an excessively large extension of the total combustion time.

For the concentration of $\mathrm{CO}_{2}=7.7 \%$ achieved in combustion stage $\mathrm{I}$, the heat released by burning $\mathrm{CO}$ will be equal to:

$$
Q_{C O}^{r}=\left(0.0548929+0.023736 H_{i}^{i}\right) \frac{34.7-1.65 \cdot 7.7}{100} \cdot 12644=995.8 \frac{k J}{m_{N}^{3}}
$$

This heat obtained by combustion of $\mathrm{CO}$ and is released at the same time as the combustion of the upper layer of poultry waste, but representing an insufficient thermal support. Thus, stoichiometrically, for the biomass considered having the lower calorific value equal to $H_{i}^{i}=14 \mathrm{MJ} / \mathrm{kg}$, the volume of flue gases having the value of $4.63 \mathrm{~m}_{N}^{3} / \mathrm{kg}$, the total heat accumulated by combustion will be $3023.7 \mathrm{~kJ} / \mathrm{m}_{N}^{3}$. The thermal participation of $\mathrm{CO}$ combustion in the second combustion stage results $\frac{995.8}{3023.7}=0.32=32 \%$, supporting the combustion of poultry manure.

The second stage combustion solution involves a low density of fuel in the layer $\left(\rho_{c}<250 \mathrm{~kg} / \mathrm{m}_{N}^{3}\right)$. If the correspondence with the porosity coefficient $\mathrm{m}$ is considered by the relation:

$\mathrm{m} \approx \frac{\rho_{c}}{\rho_{o}}$

where $\rho_{o}=1000 \mathrm{~kg} / \mathrm{m}^{3}$ is the absolute density for biomass, the porosity results in this case less than the value $\mathrm{m}$ $=0.25$ enabling an easy penetration of air. The physical model of combustion is shown in Figure 2 . 


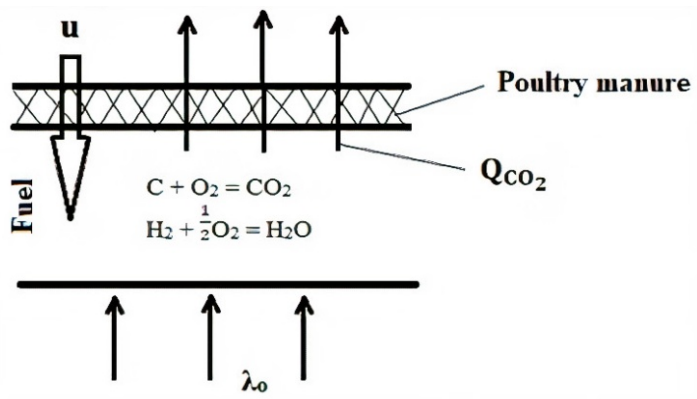

Fig. 2. Combustion in a fixed bad of fuel with high density (porosity).

The combustion rate $\mathrm{u}$, in $\mathrm{m} / \mathrm{s}$, represents the rate of decrease of the fuel layer height. The higher it is, the more the heat released by combustion is transmitted directly to the upper poultry manure layer.

The combustion rate is determined by the lower calorific value $H_{i}^{i}$ of the fuel and the density of the fuel layer $\rho_{c}$, as given in eq. (14):

$$
u=\mathrm{f}\left(H_{i}^{i}, \rho_{c}\right) \quad[\mathrm{m} / \mathrm{s}]
$$

Based on this observation, the law of heterogeneous combustion velocities q, can be expressed as in eq. (15):

$$
q=\frac{C_{o}}{\frac{1}{k}+\frac{r_{o}}{D}} \quad[\mathrm{~m} / \mathrm{s}]
$$

As a physical interpretation, the lower calorific value is attached to the combustion rate constant $\mathrm{k}$ [m/s] and the molecular diffusion density $\mathrm{D}\left[\mathrm{m}^{2} / \mathrm{s}\right]$. With $\mathrm{r}_{\mathrm{o}}[\mathrm{m}]$ was noted the radius of the fuel particle and $C_{o}$ represents the initial concentration of the oxidizing medium. The corresponding variation of the combustion rate $u$ results, compared to the combustion parameters, $H_{i}^{i}$ and $\rho_{c}$, is shown in Figure 3.

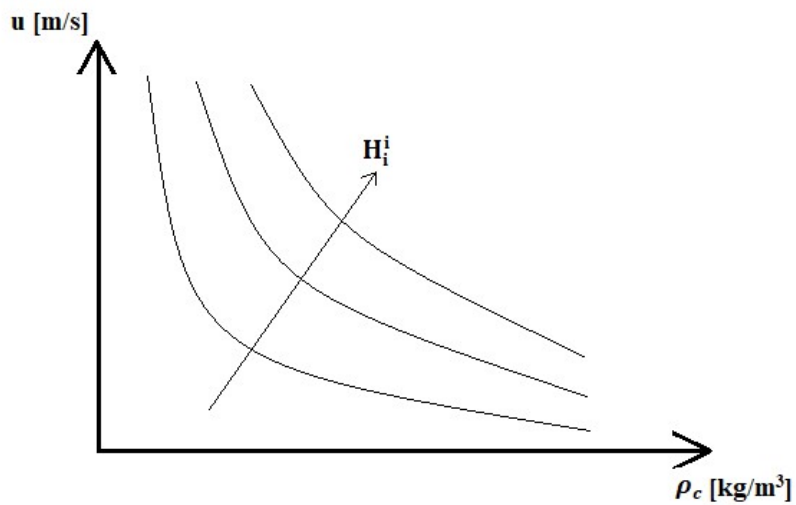

Fig. 3. Law of variation of combustion rate in a fixed layer of fuel

\section{Experimental investigation on poultry manure - solid biomass co- combustion}

The experiments conducted in this research aim to determine the efficiency of the co-combustion process depending both on the biomass quality and its bulk density. In reference to the moisture of the manure, it is highlighted that the investigations are conducted at very high humidity content of poultry manure. The combustion speed and the air diffusion behavior depending on the bulk density is observed.

\subsection{Equipment and methodology of research}

The experiments are performed at laboratory scale, employing a pilot installation comprising a boiler equipped with a fixed grill of $55 \mathrm{~kW}$, set in the Thermotechnical Laboratory of the Faculty of Mechanics and Mechatronics, Polytechnic University of Bucharest. 


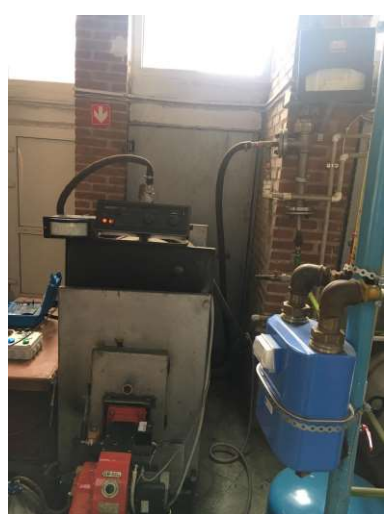

(a)

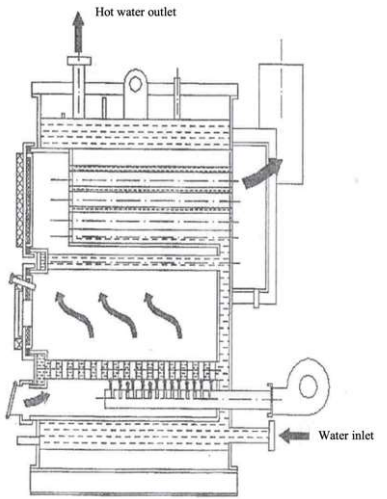

(b)

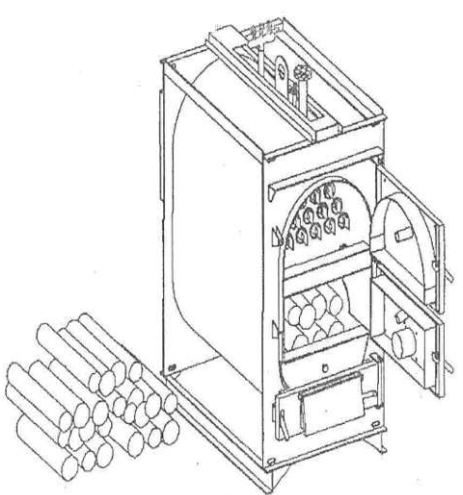

(c)

Fig. 4. Pilot installation, $55 \mathrm{~kW}$ boiler: (a) Overview; (b) Cross-sectional diagram; (c) Front diagram.

The $55 \mathrm{~kW}$ pilot boiler has the following dimensions of the hearth:

- $\quad$ length: $\mathrm{L}_{\text {hearth }}=750 \mathrm{~mm}$; width: $\mathrm{l}_{\text {hearth }}=550 \mathrm{~mm}$; height: $\mathrm{h}_{\text {hearth }}=600 \mathrm{~mm}$;

- $\quad$ hearth volume: $\mathrm{V}_{\text {hearth }}=0.25 \mathrm{~m}^{3}$;

The hearth is equipped with a fixed bars grill with the following dimensions:

- $\quad$ length: $\mathrm{L}_{\text {grill }}=520 \mathrm{~mm}$;

- $\quad$ bars width: $1_{\text {grill_bars }}=15 \mathrm{~mm}$;

- $\quad$ space between bars: $\mathrm{s}=15 \mathrm{~mm}$;

- $\quad$ grill surface: $\mathrm{S}_{\text {grill }}=0.286 \mathrm{~m}^{2}$;

- $\quad$ active surface of the grill: $S_{\text {active_grill }}=0.19 \mathrm{~m}^{2}$;

\subsection{Experimental cases}

The tests are performed in three sets of conditions. The fuel used consists of a mixture of poultry manure (collected directly from the poultry house bedding), which is spread over the fixed layer of solid biomass (wood or agricultural), in a controlled proportion. The energy characteristics of the solid biomass used for the experimental tests are analyzed according to the relevant standard methods and presented in Table 1.

\subsubsection{Case 1}

The fuel mixture used is represented by:

- $70 \%$ forest biomass, wood mixture of different species (beech, oak, hornbeam) in the form of boards of size $(2 \times 5.5 \times 25) \mathrm{cm}^{3}$, with humidity $25 \%$, lower calorific value $13200 \mathrm{~kJ} / \mathrm{kg}$ and mass $5.3 \mathrm{~kg}$;

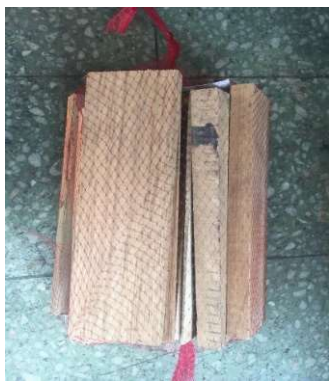

Fig. 5. Solid forest biomass in the form of planks -1 .

- $\quad 30 \%$ poultry manure, with $50 \%$ humidity, calorific value $4100 \mathrm{~kJ} / \mathrm{kg}$ and mass $1.59 \mathrm{~kg}$. In this scenario, the lower calorific value results:

$H_{i}^{i}=0.7 \cdot 13200+0.3 \cdot 4100=10470 \mathrm{~kJ} / \mathrm{kg}$ 
The volume of the fuel mixture placed in a fixed layer on the hearth grill was $(40 \times 30 \times 25) \mathrm{cm}^{3}$, the fuel layer being characterized by a low density, $\rho_{c}=226.6 \mathrm{~kg} / \mathrm{m}^{3}$.

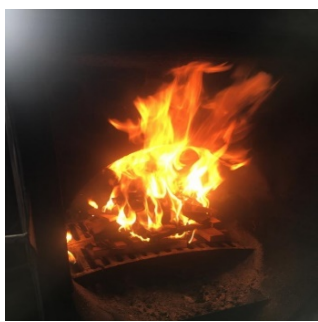

(a)

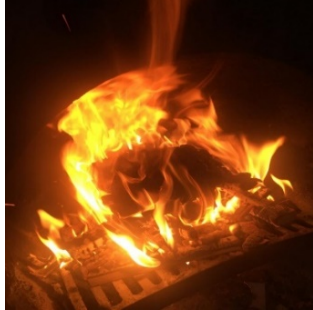

(b)

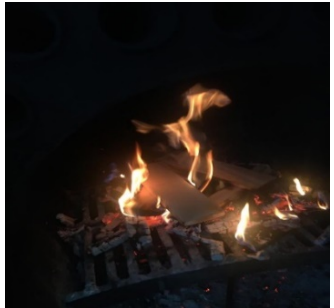

(c)

Fig.6. Experiment 1 - Images of the burning process inside $55 \mathrm{~kW}$ pilot boiler at different times of the process

a) the 3 th minute; b)the 12 th minute; c) the 17 th minute.

The burning time of the sample was $1080 \mathrm{~s}$, leading to a burning speed of $0.231 \mathrm{~mm} / \mathrm{s}$.

\subsubsection{Case 2}

The fuel mixture used is represented by:

- $\quad 80 \%$ forest biomass, wood mixture of different species (beech, oak, hornbeam) in the form of boards of size $(3.5 \times 7 \times 25) \mathrm{cm}^{3}$, maximum humidity of $25 \%$, the calorific value $13400 \mathrm{~kJ} / \mathrm{kg}$ and mass $5.0 \mathrm{~kg}$.

- $20 \%$ poultry manure, $50 \%$ humidity, calorific value $4250 \mathrm{~kg} / \mathrm{m}^{3}$ and mass $1.0 \mathrm{~kg}$.

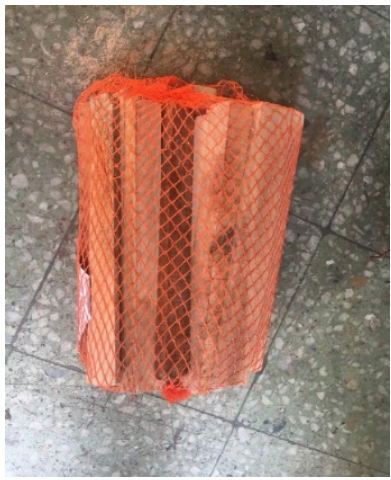

Fig. 7. Solid forest biomass in the form of planks -2 .

The calorific value of the biomass-poultry manure mixture result in this case:

$H_{i}^{i}=0.8 \cdot 13400+0.2 \cdot 4250=11570 \mathrm{~kJ} / \mathrm{kg}$

The volume of the fuel mixture placed in the fixed layer on the hearth grill is $(40 \times 30 \times 25) \mathrm{cm}^{3}$, the fuel layer being characterized by a lower layer density than in Case 1 , specifically $\rho_{c}=200 \mathrm{~kg} / \mathrm{m}^{3}$. Figure 8 shows the images of the combustion process.
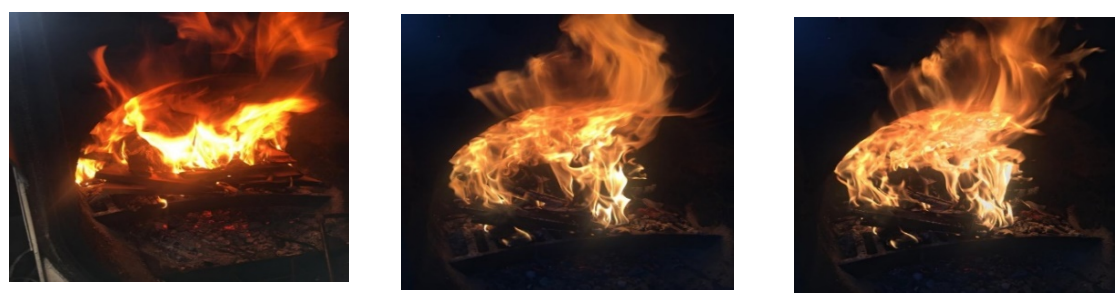
(a)

(b)

(c)

Fig. 8. Experiment 2 - Images of the burning process inside

$55 \mathrm{~kW}$ pilot boiler at different times of the process a) first minute; b) the 7th minute; c) the 9th minute.

The burning time of the sample was $1050 \mathrm{~s}$, leading to a burning speed of $0.238 \mathrm{~mm} / \mathrm{s}$.

\subsubsection{Case 3}

The fuel mixture used in this case is represented by:

- $\quad \approx 85 \%$ agricultural biomass, mixture of vines and branches with tree bark, in the form of furrows 25 $\mathrm{cm}$ long, and different thicknesses between 4 and $17 \mathrm{~mm}$, maximum humidity of $20 \%$, calorific value $13700 \mathrm{~kJ} / \mathrm{kg}$ and mass $4 \mathrm{~kg}$;

- $\quad \approx 15 \%$ poultry manure, $50 \%$ humidity and mass $0.75 \mathrm{~kg}$.

The calorific value of the biomass-poultry manure mixture results:

$H_{i}^{i}=12270 \mathrm{~kJ} / \mathrm{kg}$

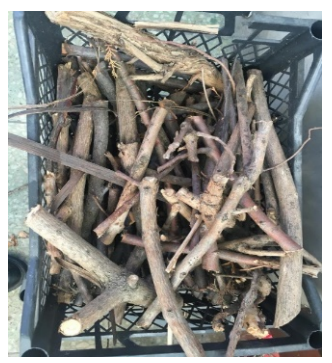

Fig. 9. Solid agricultural biomass in the form of firewood and twigs

The volume of the fuel mixture placed in the fixed layer on the hearth grill is $(40 \times 30 \times 30) \mathrm{cm}^{3}$, with the density of the fuel layer much reduced compared to the first two experiments, which facilitated rapid ignition and very intense combustion. The density of the fuel mixture was $\rho_{c}=132 \mathrm{~kg} / \mathrm{m}^{3}$.

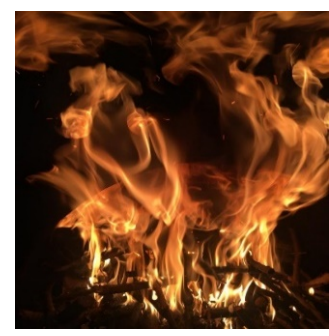

(a)

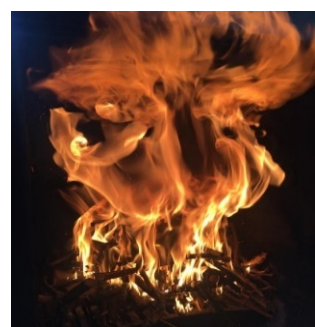

(b)

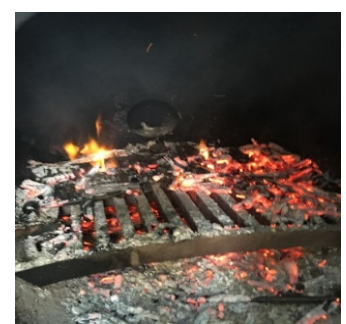

(c)

Fig. 10. Experimentul 3 - Images of the burning process inside $55 \mathrm{~kW}$ pilot boiler at different times of the process; a) first minute; b) the 3 th minute; c) the 18 th minute.

The burning time is reduced to $980 \mathrm{~s}$, and the burning speed increased to $0.306 \mathrm{~mm} / \mathrm{s}$.

\subsection{Results and discussions}

Table 2 specifies the experimental parameters for the fuel mixture used in each of the three experimental tests. 
Table 2 - Experimental parameters of the fixed layer fuel mixture

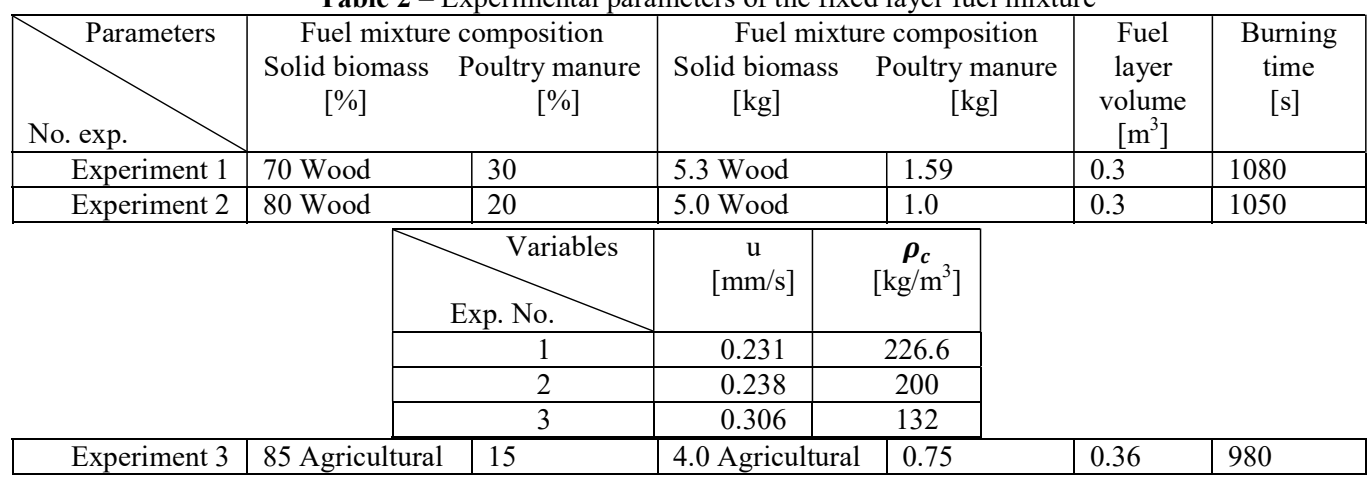

The graph in Figure 11 shows the influence of the burned fuel density $\left(\rho_{c}\right)$ containing a certain proportion of poultry waste in the technology of fixed layer combustion on the combustion rate $(u)$. Poultry waste is fed to the top of the fuel layer.

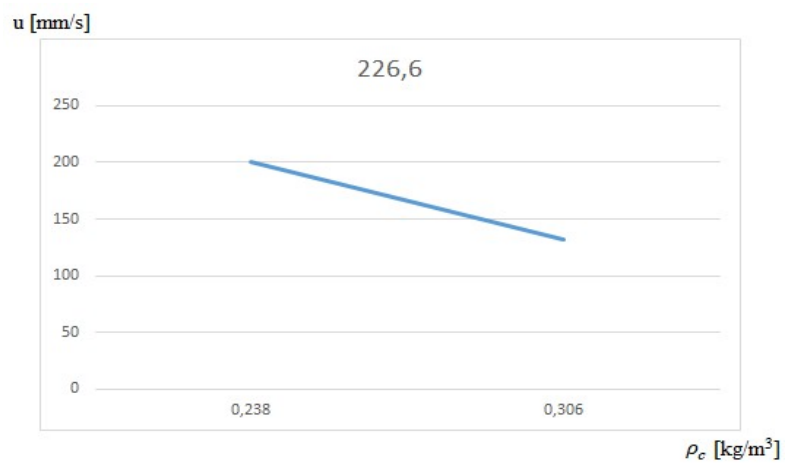

Fig. 11. The influence of fuel layer density on combustion rate

\section{Conclusions}

The co-combustion process shows great complexity, being influenced of several factors, such as: time, spatial distribution, flow currents, flue gases, (controlled) combustion rate and convection conditions. In all three experimental test conditions, the combustion (without prior mixing of fuels), is stationary, threedimensional, with turbulent flow and unfolds in a heterogeneous environment.

The combustion of volatiles, including $\mathrm{CO}$, took place in the volume between the biomass pieces and at the surface of the layer, as shown in Figures 6,8 and 10. The time of drying and release of volatile matter reaches only $10 \%$ of the biochar burning period. The amount of heat released in the combustion process is largely determined by the combustion of the biochar residue. The normal development of the combustion process is still conditioned by the design of the air supply in the biomass co-combustion layer.

A comparative analysis between the three experimental tests highlights the decrease of the burning speed with the increase of the wood pieces dimensions (Case 2), but also an increase with the decrease of the fuel density in the layer. There are no significant differences between the use of wood or agricultural biomass.

The experimental test conducted in this research highlighted the possibility of energy recovery from poultry waste by means of combustion with solid biomass.

This work was supported by a grant of the Romanian Ministry of Research and Innovation, CCCDI-UEFISCDI, project number PN-III-P2-2.1-PED- 2019-2350, within PNCDI III (contract number 322PED/2020) and project number PN-III-P11.2-PCCDI-2017-0404/31PCCD/2018, within PNCDI. 


\section{References}

1. O. Udrea and G. Lazaroiu, "RES INTEGRATION IN ROMANIA," U.P.B. Sci. Bull., Ser. C, 2015.

2. E. Brizio, G. Genon, F. Becchis, and D. Russolillo, "Renewable energy plants: Environmental compatibility and external costs assessment at global, regional and local scale," Renew. Energy Power Qual. J., vol. 1, no. 8, pp. 1015-1019, 2010.

3. International Renewable Energy Agency, "Renewable Energy Statistics 2017," 2017.

4. G. Lazaroiu, D. A. Ciupageanu, L. Mihaescu, M. Grigoriu, and I. Simion, "Energy recovery from poultry manure: A viable solution to reduce poultry industry energy consumption," Renew. Energy Power Qual. J., vol. 18, no. 18, pp. 202-206, 2020.

5. G. Lazaroiu, L. Mihaescu, R.-M. Grigoriu, D.-A. Ciupageanu, and I. Simion, "EFFICIENT POULTRY INDUSTRY WASTE MANAGEMENT APPROACH IN THE BIOECONOMY FRAMEWORK," in 8th International Conference on Advanced Materials and Systems (ICAMS), 2020, pp. 409-415.

6. E. Brizio and G. Genon, "Environmental compatibility of renewable energy plants," WIT Trans. Ecol. Environ., vol. 136, pp. 149-159, 2010.

7. F. Cotana, V. Coccia, A. Petrozzi, G. Cavalaglio, M. Gelosia, and M. C. Merico, "Energy valorization of poultry manure in a thermal power plant: Experimental campaign," Energy Procedia, vol. 45, pp. 315-322, 2014.

8. L. Mihaescu, G. Lazaroiu, I. Pisa, D.-A. Ciupageanu, and V. Berbece, "Energy valorization of poultry manure through products resulted in a pyrolysis process," in 18th International Multidisciplinary Scientific GeoConference SGEM2018, 2018, pp. 349-355.

9. G. Petrecca and R. Preto, "The use of poultry manure to produce clean electric power," 3rd Int. Conf. Clean Electr. Power Renew. Energy Resour. Impact, ICCEP 2011, pp. 676-681, 2011.

10. L. Mihaescu, G. Lazaroiu, I. Pisa, G.-P. Negreanu, V. Berbece, and D.-A. Ciupageanu, "Thermal conditions required for poultry manure combustion in furnace boilers," in 19th International Multidisciplinary Scientific Geoconference SGEM2019, Volume 19(4.1), 2019, pp. 569-576.

11. G. Lazaroiu et al., "Experimental Investigations of Innovative Biomass Energy Harnessing Solutions," Energies, vol. 11, no. 12, p. 3469, 2018.

12. R. Amirante, S. Bruno, E. Distaso, M. La Scala, and P. Tamburrano, "A biomass small-scale externally fired combined cycle plant for heat and power generation in rural communities," Renew. Energy Focus, vol. 28 , no. 00, pp. 36-46, 2019.

13. G. Lazaroiu, Holistica impactului surselor regenerabile de energie asupra mediului si climei. Vol. 2 Biomasa solida sursa de energie curata. Bucharest: Politehnica Press, 2018.

14. G. Lazaroiu, L. Mihaescu, G. Negreanu, I. Simion, and D. A. Ciupageanu, "Researches on biofuels gasification using the Lurgi process with homogeneous air inlet over the combustion space," E3S Web Conf., vol. 180, pp. 1-10, 2020.

15. I. Pîşă, G. Lăzăroiu, C. Rădulescu, and L. Mihăescu, "Experimental studies on the corrosion occurrence during biomass combustion process," Environ. Eng. Manag. J., 2012.

16. E. Pop, L. Mihăescu, G. Lăzăroiu, I. Pîșă, G. Negreanu and V. Berbece, Energy characteristics of the char obtained by two steps pyrolysis of chicken manure, XXIInd National Conference on Thermodynamics with International Participation, NACOT 2019, May 22-24, 2019, Galați, Volume 595, Issue 120 September 2019 Article number 012051, pp. 1-8, ISSN 17578981. 